\title{
Shalini Puri
}

The Grenada Revolution in the Caribbean Present: Operation Urgent Memory. New

York: Palgrave Macmillan, 2014. xiv + 341 pp. (Paper Us $\$ 35.00$ )

This book is an important and unique contribution to the literature on the Grenada Revolution, providing a politically useful exploration of New Jewel Movement governance and its ultimate violent implosion. Shalini Puri reports that she had originally envisioned her Grenada study as "a fairly recognizable literary-critical project in which my inquiry into the pasts and futures of leftist politics in the region would be mediated through close readings of the literary form of a few novels and poems" (p. 16). She concluded however that such an approach was inadequate. Faced with the contrast between a "public discursive silence on the subject of the Revolution" and "the ubiquitous visual traces of it" (ibid.), she decided to embed her arguments "in a poetics of place" (p. 26). In addition to novels and poems, she utilizes calypso, buildings, monuments, and the Grenada landscape as tools to restore memory of the "Revo" and its awful demise, when members of the People's Revolution Army shot and killed an untold number of Maurice Bishop supporters as well as Bishop himself.

Puri is explicit concerning her political objective, writing that her book "is an effort toward a democratic socialism that is both able and answerable in the present" (p. 156). While she offers "an unapologetic reclamation of its achievements," she also presents an "unapologetic rejection of some elements of the Revolution" (p. 274). Here she is unsparing in her assessment of who bears responsibility for the Revolution's collapse. It "was brought down because of its own internal blood-letting" (p. 7).

The first two chapters are straightforward summaries of the accomplishments and failures that occurred during the Revolution. Puri then focuses on an effort at restorative memory. Particularly successful in this regard is the chapter on the killings in Fort Rupert. She reproduces the reactions of a British journalist who recorded the "carnival-type atmosphere" that existed among the proBishop crowd as it marched to the Fort until she heard "the exact moment the vibe changes from triumphant party to mind-bending horror" (p. 92). Puri's discussion of reflections by those convicted of responsibility for the murders (the Grenada 17) is also quite moving. These former revolutionaries were imprisoned in the same Richmond Hill jail in which they had incarcerated purported enemies. When Puri visited the prison, she was "pressingly (sic) aware that in this space are concentrated many of the contradictions of the Revolution and its aftermath, indeed of Grenadian society itself" (p. 226).

To Puri, the prison writings of the Grenada 17 have the feel of a Greek tragedy. She cites the work of one of the leaders, Joseph Ewart Layne, who

(C) JAY R. MANDLE, 2016 | DOI: 10.1163/22134360-09001018

This is an open access article distributed under the terms of the Creative Commons 
reports that when a conflict broke out among the government's leaders, its members did not possess the political experience that would have allowed them to resolve their problems: "we were not skilled in the art of compromise. It was not part of our arsenal ... our years as a movement were one of solving conflicts by confrontation or force: by 'heavy manners': that was our reflex action" (p. 235). In such a culture, disagreement could easily result in comrades being considered "counters" - counterrevolutionaries who were beyond the political pale and subject to the most stringent political punishment.

Puri describes the larger context in which these illiberal attitudes developed as "an ethos of militarism that exceeded the requirements of self-defense," arguing that "there is a fundamental contradiction between the norms of military hierarchy and of civil democracy and between the resolution of disagreement through force instead of persuasion" (p. 67). Seen in this perspective the Revolution's rigidity and top-down politics were not aberrations or mistakes, but basic flaws rooted in its intolerant political culture. That culture was also the reason for the alienation of regional supporters of the Revolution who opposed its trials without detention, the use of torture, the failure to hold elections, and the closing of newspapers. For example, Tim Hector, Walter Rodney, Raffique Shah, and David Abdulah, well-known members of the Caribbean Left, formed a delegation that went to Grenada to protest the closing of the independent Torchlight newspaper. Rebuffed, they withdrew their support for the Revolution. Bernard Coard, the most prominent figure among the Grenada 17, today concedes that closing the newspaper was a mistake. But he is still silent on the larger point that the decision to close the newspaper was the product of an environment that disallowed divergent points of view.

When the New Jewel Movement showed itself unable to manage disagreements, and instead resorted to violence, all of the political Left in the Caribbean was tarnished. To this day, Caribbean radicalism has not recovered from the violence at Fort Rupert.

\section{Jay R. Mandle}

Department of Economics, Colgate University, Hamilton NY 13346, U.s.A. jmandle@colgate.edu 